Tamás ANTAL, Szeged

\title{
Ministers of Justice in Hungary during the Austro-Hungarian Monarchy
}

The present paper provides information about the Ministers of Justice in the period of the so-called "bourgeois age" when the Austrian Empire and the Hungarian Realm established a special connection of states commonly known as the Austro-Hungarian Monarchy. The matters of jurisdiction and judicature were not in the scope of authority of the common organs, therefore the Ministers of Justice were members of the national governments on both sides. The author summarizes and evaluates the lives and works of the most important Hungarian ministers in minibiographies as well as the professional relationship between those gentlemen who had the same political and professional roots.

Keywords: 19-20 th centuries - Austro-Hungarian Monarchy Biography-

Hungarian public law - Judicature - Minister of Justice

\section{Introduction}

The Hungarian Royal Ministry of Justice was organized pursuant to Act III of 1848 by the very first sectoral minister, Ferenc Deák (known as Franz von Deák in Austria), ${ }^{1}$ in the spring of 1848, after the responsible Government had been appointed by Archduke Stephan, the last Palatine (the highest dignitary of the state following the King) in Hungary. ${ }^{2}$ During the Hungarian War of Independence (1848-49) against the Habsburg Empire, Bertalan Szemere, then Sebő Vukovich headed the national administration of justice. ${ }^{3}$ In this paper, I am going to briefly present the courses of life of those Ministers of Justice in the Hungarian govern-

\footnotetext{
${ }^{1}$ Ruszoly, Vom Standpunkte 235-267; BALOGH, Strafrechtskodifikation 12-13; STIPTA, Selbstverwaltungskonzeption 267-280; OLECHOWSKI, Dezemberverfassung 3-15, IDEM, Az 1867, 150-156.

2 RuszOLY, Neue Verfassung 93-111; VARGA, Acts 14-20.

${ }^{3}$ SARLós, Deák és Vukovics 78-101; ERdóDY, HERMANN, Batthyány és Szemere 165-327; Ruszoly, Bertalan Szemere 45-53.
}

ments after the Compromise of 1867 - which established the Austro-Hungarian dual monarchy ${ }^{4}$ - who were especially outstanding juristpoliticians.

There exists one further connection between them: the first sectoral minister of Dualism, Boldizsár Horvát, invited the then young Dezső Szilágyi to work in his office, while two decades later it was Szilágyi who appointed Sándor Erdély, Sándor Plósz and Jenő Balogh as undersecretaries of state and ministerial councillors, who were his successors later in this position. Thus, Szilágyi and his contemporaries chosen by him determined the activities of the Ministry of Justice for a quarter of a century. They were the colleagues of such Austrian lawyers and lawmakers as Anton Julius Glaser, Friedrich Schönborn and Franz Klein. ${ }^{5}$

\footnotetext{
${ }^{4}$ MÁtHÉ, Institutionelles System 406-412; STIPTA, Zweihundert Jahre 221-233.

${ }^{5}$ BRAUNEDER, Juristen 184-189, 234-242; LEHNE, Schönborn Friedrich 57-58.
} 


\section{Boldizsár Horvát (1867-1871)}

He was born in Szombathely on 1 January 1822. He completed his studies at the academy of law in Györ; then in 1843, when he was barely 20 years old, he passed the sworn barristers' examination and opened an office in his hometown. Besides engaging in practice, he soon developed receptiveness to the revived political life, as a result of which he became a Member of Parliament in 1848 in the borough of Szombathely, and in 1849 he followed the House of Representatives from Budapest to Debrecen, the "capital of the war of independence". He could continue practicing law from 1850. In 1861 he was a member of the National Judicial Conference ${ }^{6}$ and was reelected to Parliament. In 1862 he travelled abroad, and on returning home he established the Land Credit Institute and also became one of its leaders as Director of Legal Affairs. In 1865 he was reelected to be a representative in Parliament; then, relating to the process of pardon negotiations upon the proposal made by Ferenc Deák and Gyula Andrássy on the Hungarian side, Ferdinand von Beust on the Austrian side ${ }^{7}$ - the King appointed him as Minister of Justice on 19 February 1867 . He undertook the most difficult task: to carry out the first judicial organizational and procedural reforms separating public administration and the power of jurisdiction. Despite their success, the conservative aristocracy exerted significant political pressure on him, which made him leave his office in 1871; however, he remained a liberal politician until the end of his life.

\footnotetext{
${ }^{6}$ A high conference of lawyers was held in Budapest in 1861 to decide how to modify the Hungarian common law and former statutes under the new constitutional conditions (Diploma of October 1860) with special attention to private law affairs and the influence of the Austrian legal system. See: BALOGH, Österreichisches Recht 123-135; HOMOKI-NAGY, Geschichte 463-466, 481-492.

${ }^{7}$ OlECHOWSKI, Dezemberverfassung 4-6; BRAUNEDER, Österreichische Verfassungsgeschichte 181-186; RuszOLY, Európai alkotmánytörténelem 536-537.
}

He was elected a honorary member of the Hungarian Academy of Sciences in $1868 .^{8}$ He died on 28 October 1898.

Dezső Szilágyi described his former mentor's legal career as follows: "He believed and perhaps trusted too much in the transformative effect of institutions based on equal rights and in the unifying power of the nation. He trusted too much in the unselfishness and helpfulness of society. In his mind's eye, he had ideals: the traditions of the period of the forties and fortyeight. [...] He wanted a kind of judiciary that was strong in knowledge, its sense of responsibility and traditions, surrounded by the trust of the nation because it was independent and scrupulously true to its task; a barristers' bar, guided and inspired by the noble perception of their profession, the purity of which is guarded by themselves; procedures which were regarded by the cultured West as the best guarantee for protecting and enforcing law; a humane spirit in the material [legal] acts, which gives moral strength to law by lessening its rigorism and makes the acts long-lasting because they are built on the noble nature of man." 9

\section{Tivadar Pauler (1872-1875, 1878-1886)}

He was born in Buda on 9 April 1816, the son of Gyula Pauler, historian and academician, and he himself was the father of Ákos Pauler, later a philosopher. He taught at the academy of law in Zagreb from 1838 and at the academy of law in Győr in 1848, then still in that year he became a professor at the University of Budapest, where

\footnotetext{
${ }^{8}$ KENYERES, Horvát Boldizsár, Magyar Életrajzi Lexikon I, 742; MÁTHÉ, Az Igazságügyi Minisztérium 12, 15; MeZEY, Deák és Horvát 73-88; LAKY, Horvát Boldizsár 89-99; PÉTERVÁRI, One Empire 133-139; RADY, Nonnisi in sensu 10-11, 15-16.

9 SZILÁGYI, Horvát Boldizsár ravatalánál 542-543.
} 
he taught criminal law, and in the academic year of 1861/62 he also held the office of university rector. In 1869 he became a judge of the national supreme court, the Royal Curia, then from 1871 he was Minister of Religion and Education, from 1872 to 1875 he served as Minister of Justice in several governments, and from 1878 in the Government of Count Kálmán Tisza, an emblematic politician of that age, until his death on 30 April 1886. He became a Member of Parliament in 1871, a full member of the Hungarian Academy of Sciences in 1858, and the vice-president of the latter in 1880. As a scholar he engaged mainly in criminal law and natural law; his monograph entitled Book of Criminal Law, which was published several times - for the first time in 1864/65 -, defined the practice of law for decades, and as a philosopher he represented late natural law. From among his long ministerial activities, the reorganization of jurisdiction, the establishment of modern chambers of lawyers and notaries, the initiation of codifications in substantive and procedural law and the adoption of the criminal codes should be pointed out. ${ }^{10}$

Gyula Kautz, also his contemporary, praised him with the following words: "A bold conception, a radical interference into the order or the course of matters was not in his nature; yet the same feature of his character, which feature is never to be underestimated in a statesman, served as a guarantee that what left his hands was well thought-over and elaborate work both in essence and in detail -, with nothing to change or withdraw urgently, and with inherent guarantees for permanence. So Pauler as a statesman was always guided by this principle: 'first measure, then dare!', which means that in politics it is imprudent to upset the status quo

\footnotetext{
${ }^{10}$ KenYeres, Pauler Tivadar, Magyar Életrajzi Lexikon II, 374; MIKLÓs, Ferenc József 100-124; FINKEY, A magyar 151-158; NAGY, Régi és új 65-67.
}

and not to be able to replace it with something better $[\ldots]^{\prime \prime} .{ }^{11}$

\section{Dezső Szilágyi (1889-1895)}

He was born in Oradea [Nagyvárad] on 1 April 1840 into a Calvinist intellectual family. He completed his legal studies in Pest and Vienna, then in 1865 he opened a law office in the Hungarian capital, where he also became a journalist for political dailies. It was there that he first met Ferenc Deák and Boldizsár Horvát, who supported the brilliant young jurist, so that in 1867 he could join Horvát's Ministry of Justice as presidential secretary, and in 1869 he was already councilor of the ministry. In 1870 he made a study visit to England, where he acquainted himself with criminal substantive law and procedural law and became the standardbearer for the institution of the jury in Hungary. Yet, in 1871 Károly Csemegi, his colleague and another outstanding codificator, was appointed as undersecretary of state and Szilágyi was moved to the new codification committee subordinated to the Prime Minister's Office, but this organ ceased to exist in 1874 . This was when he was appointed to be a full professor of politics (constitutional law and administrative law) as well as criminal law at the University of Budapest. He first became a Member of Parliament representing the pro-government Deák Party in 1871. In 1875 he was a fellow of the new Liberal Party (Szabadelvü Párt), but in 1878 he joined the opposition, of which he became a leading figure, while from 1886 he was a non-party politician. He returned to the Liberal Party in 1889 and was appointed Minister of Justice in Count Kálmán Tisza's Government. As perhaps the most significant jurist-politician of the era of dualism, he made long-lasting accomplishments almost in every field, from the issues of judicial

${ }^{11}$ KAUTZ, Emlékbeszéd 34-35. 
organization through the codification of procedural law to the reform of church law. Having resigned from the ministry in 1895 he was soon elected chairman of the House of Representatives in Parliament and held this position until 1898, when he left his party again and returned there only after the departure of the Prime Minister. In 1897 he was elected honorary member of the Academy and the chief secular trustee of the Danubian Reformed Diocese of the Calvinist Church. He died on 31 July 1901. ${ }^{12}$

Béla Vavrik, as president of the Hungarian Lawyers' Society, later honoured his genius with these words: „Like the granite lion of this tomb, he was a man carved from one stone, one and the same in all conditions of life - representing both the strength and the fearless courage which breaks but never bends in the long struggle that he fought for law, for the sacred purposes of the glory and the prosperity of his homeland, to which he devoted his entire life."13

\section{Sándor Erdély (1895-1899)}

He was born in Kisjenő in Bihar county on 1 August 1839. Having completed his legal studies in Pest, he obtained a doctoral degree as well and then practiced as a lawyer from 1863. In the year of the Compromise, he was appointed official second city clerk of the free royal city of Pest and then its city clerk. In 1870 he became assistant lecturer in the Court of Cassation of the Royal Curia, then in 1871 he was appointed as deputy judge in the Royal Appeal Court of Budapest and later as its ordinary judge. From 1877 he worked again in the Court of Cassation al-

12 MARKÓ, Új Magyar Életrajzi Lexikon VI, 419; ANTAL, Törvénykezési reformok 279-286; IDEM, Szilágyi Dezső 1-84; IDEM, Hundred Years 37-53; IDEM, Reforms 9-16; STIPTA, Szilágyi Dezső 137-152; HALÁsz, Egy letűnt nemzedék 177-193, 260-277, 367391.

${ }^{13}$ VAVRIK, Beszéd Szilágyi Dezső 8. ready as a justice; after the organizational reform in 1881 he was appointed ordinary supreme court judge at the Royal Curia, and in 1888 presiding judge of the Appeal Court of Budapest. Upon the decentralization of the Appeal Court mentioned, he became the first presiding judge of the Royal Court of Appeal of Győr in 1891, then the following year Dezső Szilágyi appointed him as undersecretary of state in his ministry, finally in 1895 he himself became Minister of Justice in the Government of Dezső Bánffy. For fifteen years starting from 1892, as a member of the Liberal Party, he was a Member of Parliament for one the constituencies of Trencsén county, where he was re-elected in 1910 with the program of the majority party called National Party of Work (Nemzeti Munkapárt).

In the course of his judicial career, he presided over private law cases. During his ministerial term, he completed the codifications of procedural law commenced by his predecessor by adopting the Code of Criminal Procedure and its supplementary acts (1896-97), and related to this, by reorganizing the trial by jury and by establishing the Hungarian Royal Court of Administration, which had a country-wide competence (1896). He submitted the bill for the 1898 Act on Credit Cooperatives to Parliament, and it was also him who initiated the establishment of a ministerial standing committee for drafting the Hungarian Civil Code. He died in Budapest on 14 May $1922 .{ }^{14}$

\footnotetext{
${ }^{14}$ MARKó, Erdély Sándor, Új Magyar Életrajzi Lexikon II, 384; BELLÉR, Az Igazságügyi Minisztérium 15; ANTAL, Strafverfahrensrecht 571-576; НомОКINAGY, Geschichte 492-497; see also ANTAL, Törvénykezési reformok 50-51.
} 


\section{Sándor Plósz (1899-1905)}

He was born in Pest on 10 June 1846, graduated from university also in the state capital, obtained a lawyer's degree, and soon after, he was appointed as judge in 1872. In the same year, under the organization of the University of Klausenburg [Kolozsvár], he was appointed university professor: he taught civil jurisdictional law as well as bills of exchange and commercial law; in 1881, in the same capacity, he went to the Faculty of Law of the University of Budapest, where he taught for the rest of his life. He became undersecretary of state to Dezső Szilágyi in 1894, then Minister of Justice after Sándor Erdély and retained this office from February 1899 until June 1905 in several governments. From 1895 he was also a Member of Parliament. In the meantime, he became an academician, in 1913 he was elected as vice-president of the Hungarian Academy of Sciences, and in 1914 he was also appointed to be a member of the House of Lords. His work as a scholar and minister was focused on codification: he started the preparatory work for the code of civil procedure while working with Szilágyi, which brought the first results in the reforms of procedural law in 1893. The greatest achievement of his life was the Code of Civil Procedure itself and its first commentary in 1911, which replaced the Code of Civil Jurisdiction (1868) adopted after the Compromise. He wrote a number of scholarly studies on the administration of justice, which were collected and published by the Academy after his death on 29 May 1925. ${ }^{15}$

Károly Szladits, another great Hungarian civilist, assessed his years spent heading the ministry like this: „Sándor Plósz's scholarly disposi-

\footnotetext{
${ }^{15}$ KENYERES, Plósz Sándor, Magyar Életrajzi Lexikon II, 421; KengYeL, Plósz Sándor 21-32; UEDA, Description 25-31; IDEM, Prozeßleitung 23-35; IDEM, Civil Procedure Codes 123-137; STIPTA, Zivilverfahrensrecht 543-546.
}

tion was difficult to reconcile with his position of minister. He was not a man of action although he never feared responsibility. He had the higher kind of courage about which he himself said: 'Brave is not the person who is not afraid because he has only good nerves; brave is the one who is afraid of peril, yet he takes it on'. For him, being a minister was a sacrifice that he made in order to help accomplish the code of [civil] procedure."16

\section{Antal Günther (1907-1909)}

He was born in Székesfehérvár on 23 September 1847. A member of the order of Piarists between 1863 and 1868, he left the monastic bonds before being ordained and began his studies at the University of Budapest at the faculty of law. After graduation as a doctor of law he established his own barrister's office and also became a reviser at the bureau of the official shorthand reporters of the Hungarian Parliament in 1869. In parallel he worked for the well-known daily newspaper Pesti Napló as a journalist and legal expert between 1871 and 1894; later he was employed at other dailies, too. In 1901 he was elected a representative in Parliament with the program of the Liberal Party, but in 1905 he joined the other political side, the Party of Independence and 1848. He became a state secretary in the Ministry of Justice the following year and the Minister himself in 1907. Günther occupied this post no longer than 1909 when he was appointed president of the Hungarian supreme court, the Royal Curia, and he headed this high forum until the end of his life. He died in Budapest on 24 February 1920. During his time as Minister of Justice the first complete modifications of the Criminal Code of 1878 and the Act on Distraining of 1881 were enacted by Parliament, as well as the increase of the salary of

16 SZLADITS, Plósz Sándor 89-90. 
judges in 1908 and the establishment of the Court of the Royal Earl Marshal (Főudvarnagyi Bíróság) for the pleas in connection with the King's real properties. ${ }^{17}$

According to the memorial laudation by Mihály Herczegh, a university professor of private law, Günther's ars poetica was the following: "If we do not use equity, the so-called 'substantial justice', the condition: summus jus summa injuria, summus jus summa crux sets in. It cannot be accepted in jurisdiction, as the ex-president had said, not even if the cases seem to be similar to each other sometimes, because frequently just a small difference makes an important influence on the essence of a concrete case." 18

\section{Jenő Balogh (1913-1917)}

He was born in Devecser in Veszprém county on 14 May 1864. In 1888, immediately after completing his legal studies, he became a lecturer at the University of Budapest in the field of criminal law. After a short court service in 1891, he too was invited by Dezső Szilágyi to take part in the preparatory legislative work in the Ministry of Justice, where he was one of the main figures in the successful codification of the Code of Criminal Procedure and its supplementary acts (1896-97). Thereafter, in 1897 he was appointed an appeal court judge, and from 1900 he again taught criminal law at the University of Budapest already as a full professor. In 1910 he became a Member of Parliament with a program agreeing with that of the majority party, the National Party of Work, and was also appointed undersecretary of state in the Ministry of Education. He served as Minister of Justice in the Government of Count István Tisza, son of Kálmán

${ }^{17}$ MARKÓ, Antal Günther, Új Magyar Életrajzi Lexikon II, 1143; BóDINÉ BELIZNAI, Günther Antal 46-143; IDEM, Hogy a minimumra 14-16.

${ }^{18}$ Herczegh, Günther Antal 7.
Tisza mentioned above, from 1913 to June 1917. He was elected to be a full member of the Hungarian Academy of Sciences in 1912. After the World War he retired from politics and was more engaged in scholarly activities: he served as general secretary of the Academy between 1920 and 1935, and as its vice-president between 1940 and 1943. In 1932 he joined the Upper House of Parliament as the secular president of the Reformed Universal Convention of the Protestant Church, where he was primarily concerned with issues of public welfare, public education and foreign affairs, and he also supported the contemporary patronage movement. $\mathrm{He}$ died on 15 February 1953. His wide-ranging scholarly activities centred on the theory and practice of criminal procedural law, prison matters and the emerging field of criminology, as well as juvenile criminal law; his methodology was permeated by the experience of engrossment. ${ }^{19}$

In the most recent academic literature, István Stipta appraised his life with these words: "He was in possession of extensive literacy and immense professional knowledge. [...] He was a professor who listened to his students, who not only wrote a textbook but also conveyed legal ethos. His approach to teaching the history of law, which emphasized the importance of preserving historical values, refused the overrating of internal development and propagated outward-looking analysis, is still worthy of attention and following." 20

\footnotetext{
${ }^{19}$ KENYERES, Balogh Jenő, Magyar Életrajzi Lexikon I, 98; BÓDINÉ BELIZNAI, Balogh Jenő életútja 1-9; STIPTA, Balogh Jenő az igazságügy 40-45; KÓNYÁNÉ KUTRUCZ, Balogh Jenő emlékkötet 240-253; see also FINKEY, A magyar 195-209; NAGY, Régi és új 73-75; ANTAL, Strafverfahrensrecht 570-574.

${ }^{20}$ STIPTA, Balogh Jenő és a büntető 38.
} 


\section{Epilogue}

The legacy that these gentlemen left to posterity is of such great importance that without it the Hungarian state could not have reached its historical golden age before the First World War, which it has not been able to come close ever since. The codifications, which were in the center of their activity, are still exemplary both methodologically and in terms of content - this is also reflected by the negative experience of the accel- erated lawmaking process of our age, and more precisely by the obvious contrast in quality.

At last let us list the names of the other gentlemen who occupied the post of Minister of Justice in the period under discussion here: István Bittó (1871-72), Béla Perczel (1875-78), Teofil Fabiny (1886-89), Bertalan Lányi (1905-06), Géza Polónyi (1906-07), Sándor Wekerle (1909-10), Ferenc Székely (1910-13), Vilmos Vázsonyi (1917, 1918), Károly Grecsák (1917-18), Gusztáv Tőry (1918) and Barna Búza (1918).

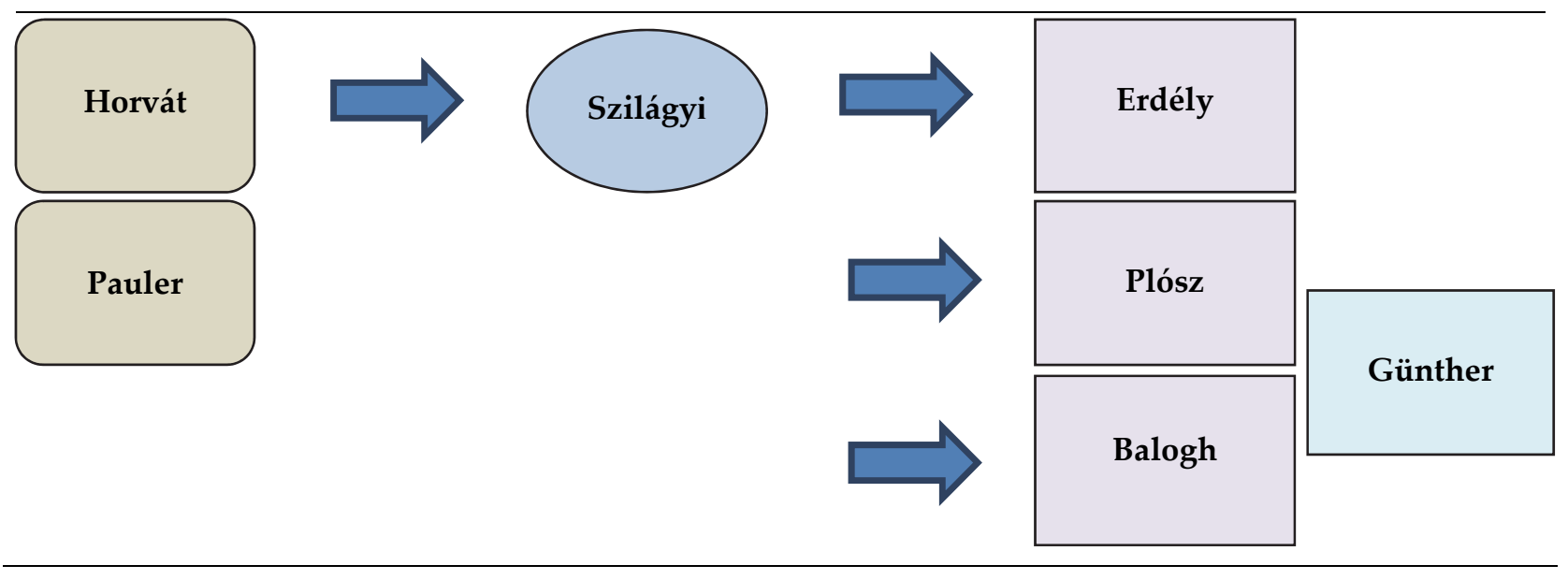

\section{Correspondence:}

Assoc. Prof. Dr. Tamás ANTAL

University of Szeged

Department of European Legal History

antalt@juris.u-szeged.hu

ORCID: 0000-0002-3874-5978

\section{Literature:}

Tamás ANTAL, A Hundred Years of Public Law in Hungary (1890-1990). Studies on the Modern Hungarian Constitution and Legal History (Novi Sad 2012).

IDEM, Das Strafverfahrensrecht (1867-1944), in: Gábor MÁTHÉ (ed.), Die Entwicklung der Verfassung und des Rechts in Ungarn (Budapest 2017) 565-595.

IDEM, Reforms of the Judicial System in the Era of Dezső Szilágyi, in: Imre SzAbó (ed.), Ius et legitimatio (Szeged 2008) 9-16.

IDEM, Szilágyi Dezső és műve (Szeged 2016).
IDEM, Törvénykezési reformok Magyarországon (1890-1900). Ítélőtáblák, bírói jogviszony, esküdtszék (Szeged 2006).

Elemér BALOGH, Die ungarische Strafrechtskodifikation im 19. Jahrhundert (Berlin 2010).

Judit BALOGH, Österreichisches Recht in Ungarn und in Siebenbürgen. Westeuropäische Einflüsse auf die ungarische Zivilrechtskodifikation im 19-20. Jahrhundert, in: Martin POLASCHEK, Anita ZIEGERHOFER (eds.), Recht ohne Grenzen - Grenzen des Rechts. Europäisches Forum Junger Rechtshistorikerinnen und Rechtshistoriker (Bern 1998) 123135.

Judit BELLÉR, Az Igazságügyi Minisztérium történetéből (1890-1899), in: Jogpolitika 4 (1983) 15.

Kinga BóDINÉ BelizNAI, „Hogy a minimumra legyen szállítva bíróhoz való hozzáférhetés esélye" - A bírói fizetésrendezés és a bírók anyagi függetlensége, 1869-1920, in: Állam- és Jogtudomány 2 (2018) 3-35.

IDEM, Balogh Jenő életútja, in: Jogtörténeti Szemle 1 (2016) 1-9. 
IDEM, Günther Antal, a „szürke ember”? (1847-1920), in: IDEM. (ed.), A Kúria és elnökei III (Budapest 2015) 46-143.

Wilhelm BRAUNEDER (ed.), Juristen in Österreich. 1200-1980 (Wien 1987).

IDEM, Österreichische Verfassungsgeschichte (Wien 51989).

Gábor ERDŐDY, Hermann RóBERT, Batthyány és Szemere (Budapest 2002).

Ferenc FINKEY, A magyar büntetőperjogi tudomány háromszázados fejlődéstörténete, 1619-1914 (Sárospatak 1948).

Imre HALÁsz, Egy letűnt nemzedék. Szilágyi Dezső, in: Nyugat 15-17 (1911) 177-193, 260-277, 367-391.

Mihály Herczegh, Günther Antal és a, in: Budapesti Hírlap Nr. 56 v. 5. 3. 1920, 7.

Mária HoMOKI-NAGY, Geschichte der zivilrechtlichen Kodifikation, in: Gábor MÁTHÉ (ed.), Die Entwicklung der Verfassung und des Rechts in Ungarn (Budapest 2017) 451-500.

Gyula KAUTZ, Emlékbeszéd Pauler Tivadar akadémiai másodelnök felett, in: A Magy. Tud. Akadémia évkönyvei, XVII/V. (Budapest 1887) 21-39.

Miklós KengYel, Plósz Sándor (1846-1925), in: Gábor HAMZA, Iván SIKLÓsI (eds.), Magyar jogtudósok IV. (Budapest 2014) 21-32.

Ágnes KENYERES et al. (eds.), Magyar Életrajzi Lexikon (Budapest 1967-1981).

Katalin KóNYÁnÉ KutRUCZ (ed.), Balogh Jenő emlékkötet. Válogatás Balogh Jenő műveiből (Budapest 1988).

Ferenc LAKY, Horvát Boldizsár, a polgári jogfejlődés katalizátora, in: Norbert CSIBI et al. (eds.), Deák és utódai. Magyar igazságügyi miniszterek 1848/49ben és a dualizmus korában (Pécs 2004) 89-99.

Friedrich LEHNE, Schönborn, Friedrich Gf., in: Österreichisches Biographisches Lexikon 1815-1950, vol. 11 (Wien 1957-2015) 57-58.

László MARKÓ (ed.), Új Magyar Életrajzi Lexikon (Budapest 2001-2007).

Gábor MÁTHÉ, Az Igazságügyi Minisztérium történetéből (1867-1871), in: Jogpolitika 3 (1982) 12; 4 (1982) 15.

IDEM, Das institutionelle System des ungarischen Rechtsstaates und die Doppelmonarchie, in: IDEM. (ed.), Die Entwicklung der Verfassung und des Rechts in Ungarn (Budapest 2017) 403-450.

Barna MEzEY, Deák Ferenc és Horvát Boldizsár, in: Norbert CSIBI et al. (eds.), Deák és utódai. Magyar igazságügyi miniszterek 1848/49-ben és a dualizmus korában (Pécs 2004) 73-88.
Tamás P. MiKLós, Ferenc József „kedvenc minisztere”. Pauler Tivadar (1816-1886) élete és pályafutása, in: Norbert CSIBI et al. (eds.), Deák és utódai. Magyar igazságügyi miniszterek 1848/49-ben és a dualizmus korában (Pécs 2004) 100-124.

Ferenc NAGY, Régi és új tendenciák a büntetőjogban és a büntetőjog-tudományban (Budapest 2013).

Thomas OleCHOWSKI, Az 1867. évi osztrák Decemberi Alkotmány: alkotmányosság - alapjogok - közjogi bíráskodás, in: Jura 2 (2017) 150-156.

IDEM, Die österreichische Dezemberverfassung 1867. Konstitutionalismus - Grundrechte - Gerichtsbarkeit des öffentlichen Rechts, in: Díké 1 (2019) 3-15.

Máté PÉTERVÁRI, One Empire and Two Ways of Public Administration. The Second Level Administrative Division in Austria-Hungary, in: Journal on European History of Law 2 (2018) 133-139.

Martyn RADY, Nonnisi in sensu legum? Decree and Rendelet in Hungary (1790-1914), in: Hungarian Historical Review 1 (2016) 5-21.

József Ruszoly, „Eine neue Verfassung für Ungarn”. Zur Einfügung der Institutionen Parlamentarismus und Volkrepräsentation in Ungarn und in dem mit ihm wiedervereinigten Siebenbürgen im Jahr 1848, in: IDEM., Beiträge zur neueren Verfassungsgeschichte. Ungarn und Europa (Budapest 2009) 93-111.

IDEM, „Vom Standpunkte der Geschichte des ungarischen öffentlichen Rechts“. Der „Beitrag” (Adalék) von Ferenc Deák und der österreichischungarische Ausgleich von 1867 im Spiegel der Historiographie, in: IDEM, Beiträge zur neueren Verfassungsgeschichte. Ungarn und Europa (Budapest 2009) 235-267.

IDEM, Bertalan Szemere im Komitat Borsod. Ein Grundriss, in: DERS., Beiträge zur neueren Verfassungsgeschichte. Ungarn und Europa (Budapest 2009) 45-53.

IDEM, Európai jog- és alkotmánytörténelem [European Law and Constitution History] (Szeged 2011).

Béla SARLós, Deák és Vukovics. Két igazságügyminiszter (Budapest 1970).

István STIPTA, Balogh Jenő és a büntető perjog, in: Jogtörténeti Szemle 1 (2016) 31-40.

IDEM, Balogh Jenő, az igazságügy református minisztere, in: Jogtörténeti Szemle 4 (2017) 40-45.

IDEM, Das Zivilverfahrensrecht, in: Gábor MÁTHÉ (ed.), Die Entwicklung der Verfassung und des Rechts in Ungarn (Budapest 2017) 541-563.

IDEM, Die Selbstverwaltungskonzeption von Ferenc Deák, in: IDEM, Die vertikale Gewaltentrennung (Budapest 2005) 267-280. 
IDEM, Die Zweihundert Jahre der ungarischen Rechtsgeschichtswissenschaft, in: IDEM., A magyar jogtörténet-tudomány kétszáz éve (Szeged 2015) 203-233.

IDEM, Szilágyi Dezső és az igazságügyi modernizáció, in: Norbert CSIBI et al. (eds.), Deák és utódai. Magyar igazságügyi miniszterek 1848/49-ben és a dualizmus korában (Pécs 2004) 137-152.

Dezső SzILÁGYI, Horvát Boldizsár ravatalánál, in: Akadémiai Értesítő Nr. 11 v. 15. 11. 1898, 541-544.

Károly SzLADITS, Plósz Sándor, in: Jogtudományi Közlöny 12 (1925) 89-90.

Rieko UeDA et al., Plósz, Alexander: Die Prozeßleitung des Gerichts nach der neuen ungarischen $\mathrm{Zi}$ vilprozeßordnung 1912, in: Kumamoto Law Review 137 (2016) 23-35.
IDEM, A brief description of Sándor Plósz. The drafter of the Hungarian civil procedural law under the Austro-Hungarian Dual Monarchy, in: Memoirs of the Faculty of Education, Kumamoto University 66 (12. 2017) 25-31.

IDEM, Austrian and Hungarian civil procedure codes from the perspective of Japanese lawyers. A Focus on Taisho period revisions of the civil procedure code (1926), in: Tamio MitomA, Jenő SzMODIS (eds.), Law, Rights and Social Values in Japan and Hungary (Aichi 2019) 123-137.

Norbert VARGA (ed.), The Acts of 1848 in Hungary (Szeged 2012).

Béla VAVRIK, Beszéd Szilágyi Dezső síremlékének leleplezése alkalmából, in: Magyar Jogászegyleti Értekezések 289 (Budapest 1908) 3-8. 